\title{
STAVOVI PREMA PRETILIM OSOBAMA U PROCESU SELEKCIJE I ZAPOŠLJAVANJA ${ }^{1}$
}

\author{
Claudia Marijan \\ Ericsson Nikola Tesla \\ Dr. sc. Maja Kolega \\ Sveučilište Vern'
}

\section{SAŽETAK}

Osobe s prekomjernom tjelesnom težinom mogu biti diskriminirane u procesu selekcije i zapošljavanja. Zbog moguće diskriminacije ljudi na temelju pretilosti, cilj ovog rada je istražiti stavove studenata menadžmenta prema pretilim osobama i doznati kakvi su njihovi stavovi prema zapošljavanju pretilih osoba. Istraživanje je provedeno među studentima Sveučilišta Vern, smjerova Ekonomije poduzetništva i Poduzetničkog menadžmenta. Istraživanje je provedeno online upitnikom i upitnikom koji je proveden na predavanjima. $U$ istraživanju su ukupno sudjelovala 134 ispitanika, od čega je 48 ispitanika muškog spola, a 86 ženskog. U upitniku je od sudionika zatraženo da uz pomoć Likertove skale stavova prema pretilim osobama i Bogardusove skale socijalne distance definiraju svoju usuglašenost s određenim tvrdnjama. Rezultati istraživanja pokazali su kako ispitanici imaju pozitivne stavove prema pretilim osobama. Također, ispitanici nemaju negativan stav prema pretilim osobama prilikom zapošljavanja. Bogardusovom skalom socijalne distance zaključeno je kako ispitanicima ne smeta ako bi pretila osoba njihov radni kolega ili osoba koju zapošljavaju u svojoj tvrtki. Iz svega navedenog moguće je zaključiti kako ispitanici ne bi diskriminirali pretile osobe u procesu selekcije i zapošljavanja.

Ključne riječi: stavovi, pretilost, selekcija, diskriminacija

1 Istraživanje je provedeno u svrhu izrade specijalističkog stručnog rada na Sveučilištu VERN'. 


\section{UVOD}

Debljina ili pretilost je prekomjerno nakupljanje masnih tkiva u ljudskome tijelu u mjeri koja nepogodno utječe na zdravlje. Smatra se „modernom bolesti današnjice“ i predstavlja veliki izazov za javno zdravstvo. Medanić i Pucarin-Cvetković (2012) navode da se pretilost razvija pod utjecajem genetskih i metaboličkih faktora, okoliša te loših životnih i prehrambenih navika. Prema nekim pokazateljima, oko $60 \%$ stanovništva Hrvatske ima prekomjernu tjelesnu težinu, dok je 20 \% stanovništva pretilo (Musić-Milanović, 2010). Problem pretilosti vidljiv je već i kod djece. Prema istraživanju Europske inicijative praćenja debljine u djece (eng. Childhood Obesity Surveillance Initiative) (COSI) Europskog ureda Svjetske zdravstvene organizacije (SZO) svako treće dijete u Hrvatskoj u dobi između 8 i 9 godina imalo je prekomjernu tjelesnu masu ili debljinu (Musić Milanović, Lang Morović, Križan, 2021). Većina pretile djece ostat će pretila tijekom čitavog života, što nosi povećane zdravstvene rizike.

Prema 10. reviziji Međunarodne klasifikacije bolesti i srodnih zdravstvenih problema (MKB-10) debljina je klasificirana kao bolest. Ipak, u široj se javnosti pretilost često smatra posljedicom volje i postupaka pojedinca. To može dovesti do stigmatizacije pretilih osoba (Puhl i Brownell, 2003; Watson, Levit i Lavack, 2017) koja je vidljiva u različitim životnim situacijama. Debljina je vrlo negativno konotirana u većini razvijenih zemalja, gdje se mršavost postavlja kao ideal ljepote. Tako se i u poslovnom kontekstu uz pretile osobe često vežu različite predrasude i stereotipi. Češće ih se doživljava lijenima, sporima, manje sposobnima i produktivnima, emocionalnijima, s manjkom samokontrole i samodiscipline (Allan, Edgar i O’Kane, 2016; Klassen, Jasper, i Harris, 1993; Pingitore i sur., 1994; Swami i sur., 2008.), što može dovesti do neravnopravnog tretmana u poslovnom kontekstu. Pretile se osobe susreću s većom diskriminacijom pri zapošljavanju (Giel i sur., 2010; Morris, 2007), niže rangiranom pozicijom i manjom plaćom (Roehling, 1999) i posljedično sami sebe percipiraju manje sposobnima (Magallares, Morales i Rubio, 2011).

\subsection{Pretile osobe i profesionalna selekcija}

Pribavljanje kvalitetnih zaposlenika oduvijek je bila vrlo važna i zahtjevna funkcija odjela ljudskih potencijala. O tome kakav se kandidat odabere za određeno radno mjesto ovisi velik broj aktivnosti organizacije. Važno je pronaći osobu koja će se uspjeti prilagoditi novom radnom mjestu, kolegama, izazovima, koja će se uklopiti u organizacijsku kulturu i koja će kvalitetno obavljati svoj posao i doprinositi uspjehu organizacije.

Selekcija je proces kojim se kroz unaprijed utvrđene i standardizirane metode i tehnike odabiru oni kandidati koji najviše odgovaraju potrebama slobodnog radnog mjesta (Bahtijarević-Šiber, 1999). Selekcija se može provoditi u obliku intervjua, provjere biografskih podataka, psihologijskih testova ili provjere fizičke sposobnosti (Noe i sur., 2005.). To je zapravo evaluacijski postupak kojim se nastoji prognozirati uspješnost kandidata na određenom radnom mjestu. Selekcijski intervju je najraširenija i najčešća metoda selekcije te ona podrazumijeva razgovor između kandidata za posao i predstavnika organizacije. Kroz razgovor se nastoji upoznati kandidata, saznati njegova iskustva i znanja, upoznati ga s organizacijom, potencijalnim radnim mjestom te dužnostima i odgovornostima. Problem intervjua su subjektivnost, predrasude i druge pogreške u procjenjivanju ljudi. Čak i osobe 
s iskustvom u profesionalnoj selekciji pokazuju sklonost pogreškama socijalne percepcije (Ding i Stilman, 2005; Giel i sur., 2012). Na percepciju drugih ljudi utječu stavovi pojedinaca, posebno u smjeru da ljudi češće uočavaju one informacije koje su u skladu s njihovim stavovima. Stav se može definirati kao način vrednovanja ljudi, objekata ili ideja (Aronson, Wilson i Akert, 2005) ili kao prosudbena tvrdnja koja može biti pozitivna ili negativna u odnosu na stvari, ljude ili događaje (Robbins i Judge, 2009).

Istraživanja diskriminacije pri selekciji zaposlenika temeljem pretilosti uglavnom koriste slike ili videozapise u kojima su neki kandidati pretili, a drugi optimalne tjelesne težine. Njihovi životopisi, iskustva i obrazovanje su gotovo identični. Rezultati pokazuju da su pretile osobe uglavnom lošije procijenjene, s manje poželjnih osobina i vještina za određeno radno mjesto, od osoba optimalne tjelesne težine (Ding i Stilman, 2005; Giel i sur., 2010; Kutcher i Bragger 2004; Larkin i Pines; 1979, Pingitore i sur., 1994; Rudolph i sur., 2009; Swami i sur., 2008). Uz to, rezultati pokazuju da su pretile žene procijenjene negativnije od pretilih muškaraca (Ding i Stillman, 2005; Fikkan i Rothblum, 2005; Roehling, 2002).

Pingitore i sur. (1994) otišli su korak dalje. U svojem istraživanju također su ispitanicima prikazivali videozapise kandidata za posao te u njemu napravili malu razliku. Njihov cilj je bio prikazati istu osobu, s normalnom težinom i dok je pretila. To su ostvarili tako što su osobi optimalne tjelesne težine promijenili izgled i učinili da izgleda pretilom. Na taj način moglo se prikazati osobu s jednakim gestikulacijama, samopouzdanjem, entuzijazmom i ostalim faktorima kao pretilu osobu i kao osobu optimalne tjelesne težine, a opet istih kvalifikacija. Dakle, jedina razlika u prikazanim kandidatima je bila njihova tjelesna težina. Rezultati su ponovo pokazali da ispitanici češće biraju osobe optimalne tjelesne težine. Također, istraživanje je pokazalo da pretile žene češće dožive diskriminaciju prilikom zapošljavanja od pretilih muškaraca.

Međutim, neka recentnija istraživanja pokazuju kako mlađe generacije u manjoj mjeri diskriminiraju pretile osobe, odnosno kada se radi o kandidatu za neko radno mjesto, manje im je bitan fizički izgled osobe od vještina, sposobnosti, znanja i obrazovanja (Allan, Edgar i O' Kane, 2016). Iz toga proizlazi i glavni cilj ovog istraživanja: provjeriti kakav je stav sadašnjih studenata poslovnog smjera prema zapošljavanju pretilih osoba.

\section{METODOLOGIJA ISTRAŽIVANJA}

\subsection{Cilj i hipoteze istraživanja:}

Glavni cilj ovog rada bio je istražiti stavove studenata menadžmenta prema pretilim osobama i doznati kakvi su njihovi stavovi prema zapošljavanju pretilih osoba.

Na temelju provedenih istraživanja spomenutih u uvodu, postavljene su dvije hipoteze:

H1: Pretile će osobe biti negativnije procijenjene u kontekstu radnog ponašanja.

H2: Studenti će imati negativniji stav prema pretilim osobama nego studentice. 


\subsection{Sudionici}

Istraživanje je provedeno među studentima Sveučilišta VERN i to smjerova Ekonomije poduzetništva i Poduzetničkog menadžmenta. Ova skupina ispitanika izabrana je zbog pretpostavke kako će studenti tih smjerova jednog dana imati vlastite kompanije u kojima će zapošljavati ljude ili će pak raditi na pozicijama linijskih menadžera gdje će također sudjelovati u izboru zaposlenika. Cilj je bio istražiti njihove stavove prema pretilim osobama kako bi se mogao izvesti zaključak o tome bi li oni zaposlili osobu s prekomjernom tjelesnom težinom. U istraživanju su sudjelovala ukupno 134 sudionika, od čega je $44 \%$ sudjelovalo online putem, a $56 \%$ kontaktnim ispunjavanjem upitnika. Od ukupnog broja ispitanika, 35,8 \% je muškog spola, dok je $64,2 \%$ ženskog spola. Raspon dobi sudionika je između 19 i 40 godina ( $M=23, S D=4,4 ; D=19$ i 23).

\subsection{Instrumenti}

Upitnik je proveden na dva načina, online putem Studomatica Sveučilišta VERN' i pisanim putem na predavanjima iste ustanove. Za oba načina rješavanja bilo je potrebno pet minuta.

Za ispitivanje stavova studenata prema pretilim osobama korišteni su:

1. Likertova skala stavova prema pretilim osobama,

2. Semantički diferencijal,

3. Bogardusova skala socijalne distance (Bogardus, 1925).

Za kreiranje ljestvice stavova o pretilim osobama prije provođenja upitnika provedeno je pilot-istraživanje s 20 tvrdnji, na temelju kojeg je kreirana konačna ljestvica stavova od 9 tvrdnji. Za svaku tvrdnju sudionici su procjenjivali u kojoj mjeri se slažu s njom i to na Likertovoj skali u rasponu od 1 - u potpunosti se ne slažem - do 5 - u potpunosti se slažem. Likertova skala je najčešće korištena ljestvica za mjerenje stavova, kojom se ocjenama u rasponu od 1 do 5 izražavaju pozitivni ili negativni stavovi prema nekom objektu stava. Stav sudionika izražava se zbrojem bodova na temelju ispitanikovih odgovora. Izračunata je i mjera pouzdanosti ukupne skale, Cronbachova Alpha, i ona za ovaj uzorak iznosi $\lambda=$ 0,79 , što govori o visokoj pouzdanosti instrumenta.

Semantički diferencijal je instrument za mjerenje konotativne dimenzije značenja pojmova. Od sudionika se traži da odredi svoju konotaciju različitih pojmova. U ovom istraživanju on je uključivao fotografije ženske osobe optimalne tjelesne težine i pretile ženske osobe. Nastojalo se postići da obje fotografije prikazuju žene u što sličnijem okruženju kako bi se dojam stjecao isključivo na temelju njihovog izgleda iako se ne može u potpunosti utjecati na faktore prema kojima drugi ljudi stječu prve dojmove. Od sudionika je zatraženo da u rasponu od -3 do 3 označe svoje dojmove za obje osobe na slikama u idućim suprotnostima: brzo-sporo, uredno-neuredno, lijepo-ružno, marljivo-lijeno, otvoreno-zatvoreno, jednostavno-komplicirano.

Bogardusovom skalom socijalne distance željelo se ispitati spremnost ljudi da sudjeluju u društvenim kontaktima različitog stupnja bliskosti s pretilim osobama. Prema Bogardusu (1925), socijalna distanca pokazuje stupanj razumijevanja, bliskosti i osjećaja koji se pokazuju prema pojedincima i društvenim grupama. 


\section{REZULTATI ISTRAŽIVANJA}

Skala stavova prema pretilim osobama konstruirana je za potrebe ovog istraživanja. Ukupna aritmetička sredina Skale iznosi $M=2,75 ; S D=0,69$. Veća ocjena znači i negativniji stav prema pretilim osobama jer su sve tvrdnje istog smjera. Drugim riječima, ukupni stav prema pretilosti je prosječne ocjene. Međutim, kada se pogleda razlika među pojedinim česticama, vidi se da se sudionici uglavnom slažu da pretile osobe imaju više zdravstvenih teškoća i da se brže umaraju, što pokazuje kako su sudionici svjesni zdravstvenih posljedica do kojih prekomjerna tjelesna težina dovodi. Većina sudionika smatra kako pretile osobe nisu lijene te manje produktivne u odnosu na zaposlenike s optimalnom tjelesnom težinom. lako predrasude prema pretilim osobama nisu potvrđene, sudionici istraživanja smatraju kako pretile osobe imaju manje samopouzdanja u odnosu na osobe optimalne tjelesne težine. Zanimljivo je da se većina sudionika, njih 76 \%, ne slaže s tvrdnjom kako su pretile osobe neuredne s obzirom na to da je kroz semantički diferencijal pretila osoba $s$ fotografije statistički značajno procijenjena neurednijom.

Osnovni podaci o česticama prikazani su u Tablici 1.

Tablica 1. Aritmetičke sredine i standardne devijacije za čestice Skale stavova prema pretilim osobama

\begin{tabular}{|c|c|c|c|}
\hline & \\
\hline & M & SD & $\mathbf{N}$ \\
\hline $\begin{array}{l}\text { Pretile osobe su manje samopouzdane od osoba normalne tjelesne } \\
\text { težine. }\end{array}$ & 3,36 & 1,13 & 134 \\
\hline Pretile osobe imaju više zdravstvenih poteškoća. & 3,96 & 1,05 & 134 \\
\hline Pretile osobe se brže umaraju. & 3,90 & 1,07 & 134 \\
\hline $\begin{array}{l}\text { Pretile osobe obično su manje produktivne od ljudi normalne tjelesne } \\
\text { težine. }\end{array}$ & 2,34 & 1,17 & 134 \\
\hline Pretile osobe najčešće su same krive što su pretile. & 2,85 & 1,09 & 134 \\
\hline $\begin{array}{l}\text { Pretili zaposlenici ne mogu biti uspješni kao zaposlenici normalne } \\
\text { tjelesne težine. }\end{array}$ & 1,95 & 1,26 & 134 \\
\hline Pretile osobe su lijene. & 2,10 & 1,09 & 134 \\
\hline Pretile osobe obično su neuredne. & 1,81 & 09 & 134 \\
\hline $\begin{array}{l}\text { Jedna od najgorih stvari za pojedinca jest da postane pretio u nekom } \\
\text { trenutku života. }\end{array}$ & 2,50 & 1,25 & 134 \\
\hline
\end{tabular}

Izračunate su i razlike između muškaraca i žena u općem stavu prema pretilosti. Za provjeru razlika korišten je t-test za nezavisne uzorke. Rezultati pokazuju kako muškarci ( $\mathrm{M}=$ $2,9, S D=0,66, n=48$ ) pokazuju negativnije stavove prema pretilim osobama od žena ( $M=$ $2,6, S D=0,68, n=86)$ i ta je razlika statistički značajna $(t=-2,67, p<0,05)$. U gotovo svim tvrdnjama muškarci su u većoj mjeri pokazali negativnije stavove u odnosu na žene.

Za dublje razumijevanje stava prema pretilim osobama korišten je semantički diferencijal. Rezultati semantičkog diferencijala prikazani su u Tablici 2. 
Tablica 2. Rezultati semantičkog diferencijala

\begin{tabular}{|c|c|c|c|c|c|}
\hline & & \\
\hline & & $\mathbf{M}$ & $\mathbf{N}$ & SD & \\
\hline \multirow{2}{*}{ Par 1} & Brzo/sporo prosječna osoba & $-1,13$ & 134 & 1,39 & \multirow{2}{*}{$\begin{array}{l}t=-6,743 \\
p<0.05\end{array}$} \\
\hline & Brzo/sporo pretila osoba & 11 & 134 & 1,51 & \\
\hline \multirow{2}{*}{ Par 2} & Uredno/neuredno prosječna osoba & $-1,95$ & 134 & 1,43 & \multirow{2}{*}{$\begin{array}{l}t=-3,755 \\
p<0.05\end{array}$} \\
\hline & Uredno/neuredno pretila osoba & $-1,48$ & 134 & 1,53 & \\
\hline \multirow{2}{*}{ Par 3} & Lijepo/ružno prosječna osoba & $-1,88$ & 134 & 1,45 & \multirow{2}{*}{$\begin{array}{l}t=-4,764 \\
p<0.05\end{array}$} \\
\hline & Lijepo/ružno pretila osoba & $-1,13$ & 134 & 1,51 & \\
\hline \multirow{2}{*}{ Par 4} & Marljivo/lijeno prosječna osoba & $-1,32$ & 134 & 1,45 & \multirow{2}{*}{$\begin{array}{l}t=1,362 \\
p>0.05\end{array}$} \\
\hline & Marljivo/lijeno pretila osoba & $-1,51$ & 134 & 1,61 & \\
\hline \multirow{2}{*}{ Par 5} & Otvoreno/zatvoreno prosječna osoba & $-1,00$ & 134 & 1,68 & \multirow{2}{*}{$\begin{array}{l}t=2,048 \\
p<0.05\end{array}$} \\
\hline & Otvoreno/zatvoreno pretila osoba & $-1,35$ & 134 & 1,63 & \\
\hline \multirow{2}{*}{ Par 6} & Jednostavno/komplicirano prosječna osoba &,- 04 & 134 & 1,72 & \multirow{2}{*}{$\begin{array}{l}t=6,842 \\
p<0.05\end{array}$} \\
\hline & Jednostavno/komplicirano pretila osoba & $-1,32$ & 134 & 1,55 & \\
\hline
\end{tabular}

Za procjene na semantičkim diferencijalima između žene uobičajene težine i pretile žene korišten je t-test zavisnih uzoraka. Zanimljivo je da se razlika između dviju osoba na cjelokupnom upitniku nije pokazala značajnom (M1 = 1,22; SD1 = 6,69; $M 2=1,11$; SD2 = 6,88, $t=-1,01, p>0,05)$. Drugim riječima, pretile osobe se ne procjenjuju značajno češće negativno konotiranim pridjevima. Jednako tako, zanimljivo je da se pokazala razlika između muškaraca i žena na općoj procjeni pretilih osoba. Dakle, muškarci i žene ne razlikuju se statistički značajno u procjenama žene uobičajene težine ( $M 1=-1,26 ; S D=1,19 ; n=86 ; M 2$ $=-1,15 ; \mathrm{SD}=0,97, \mathrm{n}=48 ; \mathrm{t}=-0,58, \mathrm{p}<0,05)$. Međutim, u procjenama pretile osobe, muš$\operatorname{karci}(M=-0,73, S D=1,06, n=48)$ im pridaju manje pozitivna obilježja od žena $(M=-1,33$, $\mathrm{SD}=1,14, \mathrm{n}=86$ ) i ta je razlika statistički značajna ( $\mathrm{t}=-3,07, \mathrm{p}<0,05)$. Ovakvi rezultati su u skladu s ranije provedenim istraživanjima, prema kojima muškarci češće imaju negativne stavove prema pretilim osobama, a naročito prema pretilim ženama (Allan, Edgar $\mathrm{i}$ O'Kane, 2016; O'Brien i sur, 2013).

Kada se razlike računaju za svaki par pridjeva posebno, dobiju se značajne razlike na 5 od 6 ponuđenih parova. Zanimljivo je vidjeti kako je pretila osoba sa slike statistički značajno procijenjena sporijom, neurednijom i manje lijepom. S druge strane, pretila osoba je $u$ odnosu na osobu uobičajene težine procijenjena otvorenijom te manje kompliciranom.

Jedina razlika koja se nije pokazala statistički značajnom je razlika u kategoriji marljivo lijeno, odnosno obje osobe su procijenjene više marljivima nego lijenima. Taj odnos pojmova vrlo je značajan jer ne potvrđuje negativnu predrasudu. Prema navedenim podacima moguće je zaključiti kako ispitanici nemaju predrasude o pretilim osobama kao lijenima. $70,9 \%$ ispitanika ima konotaciju kako je pretila osoba marljiva. U ovom pitanju ženski dio sudionika je u većoj mjeri označilo krajnje lijevu ocjenu na skali prilikom ocjenjivanja fotografije s pretilom osobom. 
Konačno, istraživanjem se željelo saznati koliko je ispitanicima ugodno raditi s pretilom osobom. Stoga je napravljena Bogardusova skala socijalne distance kojom se htjelo saznati u kojoj mjeri bi ispitanicima smetalo kada bi pretila osoba živjela u njihovoj zemlji, gradu, bila radni kolega, osoba koju zapošljavaju u svojoj organizaciji, prvi susjed, blizak prijatelj, član obitelji, bračni partner ili dijete.

\section{Slika 1. Rezultati skale socijalne distance}

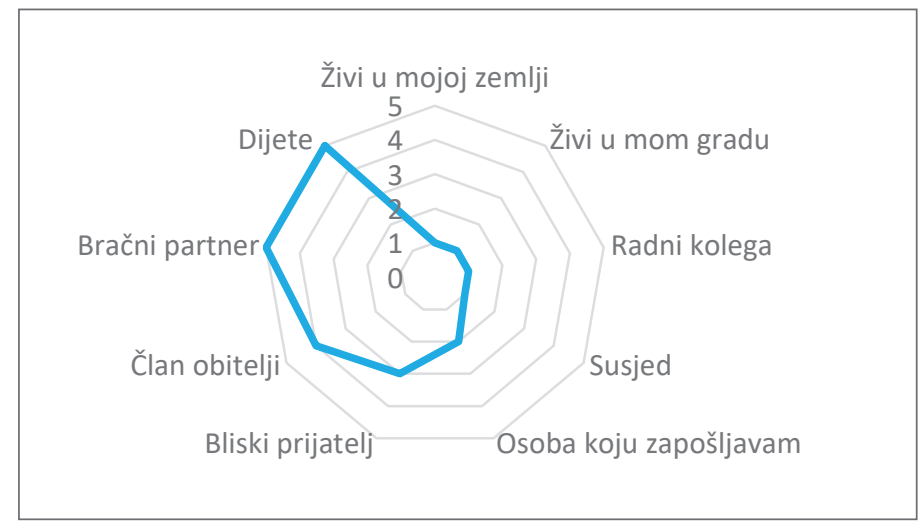

Iz Slike 1. vidljivo je kako sudionicima nije bitno ako je pretila osoba u daljnjem emocionalnom odnosu, odnosno nije direktno povezana s njihovim odnosima. Vidljivo je da kako se opis približava većem emocionalnom odnosu za pojedinca, raste i odbojnost prema pretilosti. Tako većina ispitanika ne mari previše ako je pretila osoba ona koja živi u njihovoj državi ili gradu, ali postupno raste brojka kako se približava radnom kolegi, osobi koju bi zapošljavali, a naročito raste broj kada je riječ o vrlo bliskim odnosima poput prijateljstva i obitelji. Većina ispitanika ne želi da njihov bračni partner ili dijete bude pretilo.

Vidljivo je da što je osoba ispitanicima bliža, sve im je važnije da ne bude pretila. $56 \%$ ispitanika ne bi voljelo da njihov bračni partner bude pretio, dok njih $58 \%$ ne bi voljelo kada bi njihovo dijete jednog dana postalo pretilo. Za potrebe rada od sudionika je traženo da samostalno procijene u kojoj mjeri se osjećaju pretilo.

\section{Slika 2. Samoprocjena pretilosti}

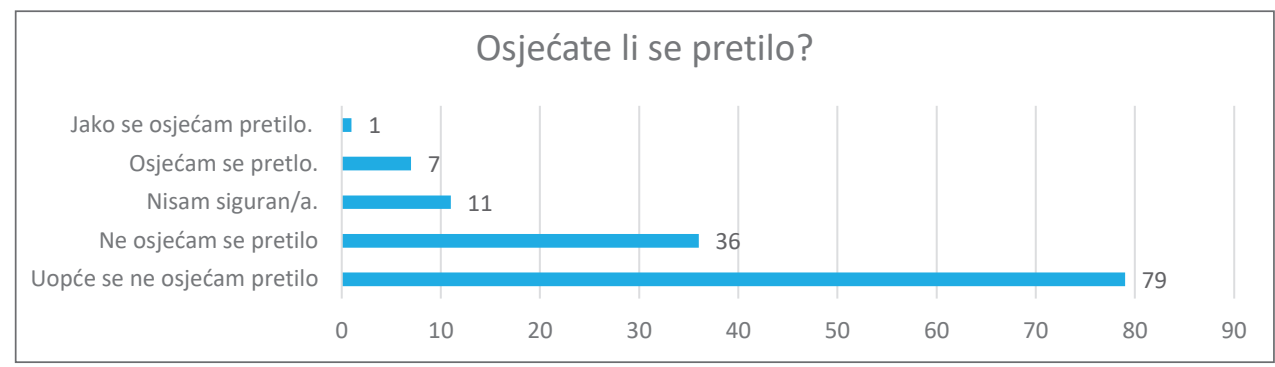


Iz Slike 2. je vidljivo kako se većina, odnosno $86 \%$ ispitanika, ne osjeća pretilo, dok se manji postotak izjasnio kao pretio. Tu je i otprilike $8 \%$ onih koji nisu sigurni ili ne mogu procijeniti pretilost. Možda bi da je u upitniku stajao način izračuna indeksa tjelesne mase zajedno s opisom svakog skupa odgovori na ovo pitanje bili drugačiji.

Izračunate su i korelacije između procjene vlastite pretilosti, dobi i ukupnog stava prema pretilim osobama. Rezultati su prikazani u Tablici 3.

Tablica 3. Korelacije između dobi, procjene vlastite pretilosti i stava prema pretilim osobama

\begin{tabular}{|l|c|c|c|}
\cline { 2 - 4 } \multicolumn{1}{c|}{} & Dob & Procjena pretilosti & Stav prema pretilima \\
\hline Dob & 1 & $\begin{array}{c}-0,33 \\
p>0,05\end{array}$ & $\begin{array}{c}-0,35 \\
p>0,05\end{array}$ \\
\hline Procjena pretilosti & & 1 & $\begin{array}{c}0,15 \\
p>0,05\end{array}$ \\
\hline Stav prema pretilima & & & 1 \\
\hline
\end{tabular}

Za provjeru povezanosti između dobi, procjene vlastite pretilosti i stava prema pretilim osobama korišten je Pearsonov koeficijent korelacije (r). Kao što je iz Tablice 3. vidljivo, povezanost među svim varijablama je mala i nije statistički značajna.

\section{DISKUSIJA I OGRANIČENJA ISTRAŽIVANJA}

Iz rezultata se može zaključiti kako sudionici nemaju izražen negativan stav prema pretilim osobama. Odgovori su pokazali kako studenti jesu svjesni posljedica koje nastaju pretilošću, a mogu biti vezane uz posao, poput toga da se pretile osobe brže umaraju i da imaju više zdravstvenih poteškoća, međutim nisu potvrđene predrasude da su pretile osobe lijene ili manje produktivne. Takvi rezultati pokazuju kako sudionici nemaju negativne stavove prema pretilim osobama te da ne bi uzeli previše u obzir činjenicu pretilosti prilikom selekcije i zapošljavanja. Ovo istraživanje u skladu je s već ranije provedenim istraživanjem na istoj dobnoj skupini, prema kojem studenti menadžmenta nemaju negativan stav prema pretilim osobama (Allan, Edgar i O' Kane, 2016). Iz rezultata provedenog istraživanja moguće je zaključiti kako studentice imaju više pozitivnih stavova prema pretilim osobama, što je također u skladu s prijašnjim istraživanjima (O’Brien i sur., 2013.). Studenti su na gotovo svim česticama negativnije procjenjivali pretilu osobu od studentica. To može ukazivati na opći negativniji stav prema pretilosti, međutim ne treba smetnuti s uma moguću veću vjerojatnost davanja socijalno poželjnih odgovora kod studentica. Važno je napomenuti kako je u odabranom uzorku bilo više studentica nego studenata, što je moglo i dovesti do pozitivnijih stavova nego kada bi taj broj bio ujednačeniji.

Zanimljivo je vidjeti razliku u nekim česticama skale za mjerenje stavova i semantičkog diferencijala. Primjerice, dok se većina sudionika ne slaže s tvrdnjom kako su pretile osobe neuredne, na semantičkom diferencijalu pretila osoba s fotografije statistički je značajno procijenjena neurednijom. To pokazuje kako postoji razlika u općenitim stavovima prema određenim skupinama ljudi i stavovima kad se suočimo s konkretnim osobama u konkret- 
nim situacijama. Semantički diferencijal smanjuje vjerojatnost socijalno poželjnih odgovora baš stoga što ne traži eksplicitno slaganje s određenim stavovima prema nekoj grupi ljudi. Tako je pretila osoba sa slike statistički značajno procijenjena sporijom, neurednijom i manje lijepom, a ujedno i otvorenijom te manje kompliciranom. Jedina razlika koja se nije pokazala statistički značajnom je razlika u kategoriji marljivo - lijeno. Takva obilježja ipak potvrđuju kako se teško maknuti od stereotipnih uvjerenja koja stvaramo na temelju vizualnog dojma. Premda opći rezultat na semantičkom diferencijalu ne odaje negativniju sliku o pretiloj osobi, u usporedbi s osobom optimalne težine, negativna obilježja poput sporosti i neurednosti mogu dovesti do lošije procjene opće radne učinkovitosti. To, drugim riječima, može značiti da bi se osobi optimalne težine ipak dala prednost pri zapošljavanju. Time se postavlja i pitanje koliko ljestvice stavova uopće mogu predvidjeti ponašanje pojedinca prema nekoj konkretnoj osobi u konkretnoj situaciji. Drugim riječima, iako deklarativno može postojati neutralan stav prema pretilim osobama, pitanje je koliko bi pretile osobe imale jednak tretman u usporedbi s osobama optimalne težine. Nadalje, prema Bogardusovoj skali socijalne distance, sudionicima ne bi smetalo kada bi radni kolege ili osobe koje zapošljavaju bili pretili. Što je osoba bliža sudionicima, pretilost se percipira kao bitniji faktor.

Konačno, treba uzeti u obzir i ograničenja istraživanja. Kako se radi o socijalno osjetljivoj temi, ovakvi rezultati istraživanja mogu biti posljedica socijalno poželjnih odgovora. Ljudi imaju tendenciju da o nekim osjetljivim temama radije daju poželjne odgovore nego iskrene kako ne bi odali dojam da imaju predrasude prema drugim ljudima. Prema tome, dobivene rezultate treba razmatrati s oprezom s obzirom na to da ne moraju odavati pravi odnos sudionika oko predrasuda prema pretilim osobama. Također, kako se sudionici nisu našli u stvarnoj situaciji da moraju birati zaposlenike, ne može se sa sigurnošću reći da u pravom selekcijskom postupku ne bi imali predrasude, odnosno da pretilost ne bi utjecala na proces selekcije. Također, nije moguće izvesti opći zaključak o pretilim osobama s obzirom na to da su u istraživanju korištene fotografije ženskih osoba. Valjalo bi vidjeti kakvi bi rezultati bili kada bi se $u$ istraživanju koristile i fotografije muškaraca s optimalnom i prekomjernom tjelesnom težinom. Isto tako, u takvom istraživanju postoji mogućnost drugačijih odgovora u odnosu na spol (Fikkan i Rothblum, 2005, Roehling, 2002). Važno je također naglasiti kako je istraživanje provedeno na malom uzorku.

Za razvoj teme diskriminacije pretilih osoba prilikom zapošljavanja trebalo bi napraviti istraživanje u kojem bi se uključile fotografije i muških pretilih osoba s obzirom na to da ranije provedena istraživanja pokazuju kako su muške pretile osobe manje diskriminirane od pretilih žena, a naročito od strane drugih muškaraca. Kao preporuka za daljnja istraživanja stoji i povećanje uzorka, ali i proširivanje na osobe koje se već bave selekcijom zaposlenika, a za koje bi provedeno istraživanje moglo poslužiti kao temelj.

\section{ZAKLJUČAK}

Diskriminacija osoba s prekomjernom tjelesnom težinom i pretilih osoba slabo je istraženo područje u Hrvatskoj. Kako se radi o vrlo osjetljivoj socijalnoj temi, nerijetko ljudi ne žele priznati da imaju predrasude prema pretilim osobama. Cilj ovog rada bio je istražiti stavove studenata menadžmenta prema pretilim osobama i odgovoriti na pitanje kako bi ti stavovi mogli utjecati na proces selekcije i zapošljavanja ako bi se isti jednog dana našli u 
takvim ulogama. Istraživanje je pokazalo da muškarci imaju nešto negativniji stav prema pretilim osobama u odnosu na žene. Ipak, prema rezultatima provedenog istraživanja, moguće je zaključiti kako sudionici nemaju negativne stavove prema pretilim osobama i da im ne bi smetalo kada bi pretila osoba bila njihov radni kolega ili osoba koju zapošljavaju u svojoj organizaciji. 


\title{
ATTITUDES TOWARDS OBESES IN THE SELECTION AND EMPLOYMENT PROCESS
}

\author{
Claudia Marijan \\ Ericsson Nikola Tesla \\ Maja Kolega, PhD \\ VERN' University
}

\begin{abstract}
Overweight and obese people may be discriminated against in the selection and recruitment process. Due to the possible discrimination of people on the basis of obesity, the aim of this paper is to investigate the attitudes of management students towards obese people and to find out what their attitudes towards the employment of obese people are. The research was conducted among students of the VERN University, majoring in Economics of Entrepreneurship and Entrepreneurial Management. The research was conducted through an online questionnaire and a questionnaire conducted in lectures. A total of 134 subjects participated in the study, 48 of which were male and 86 female. The questionnaire asked participants to define their agreement with certain statements using Likert scale of attitudes towards obese people and the Bogardus scale of social distance. The results of the research showed that the respondents have positive attitudes towards obese people. Also, respondents do not have a negative attitude towards obese people when hiring them. The Bogardus scale of social distance concluded that the respondents didn't not mind having an obese person either as their work colleague or the person they employ in their company. Based on all the above, it is possible to conclude that the respondents would not discriminate against obese people in the process of selection and employment.
\end{abstract}

Keywords: attitudes, obesity, selection, discrimination 


\section{LITERATURA}

1. Allan, P., Edgar, F., O'Kane, P. (2016). Obesity discrimination in selection: NZ Millennials reactions to obese candidates. New Zealand Journal of Human Resource Management, 16(1) special issue - The future of work, 73-89.

2. Aronson, E., Wilson, T. D., Akert, R. M. (2005). Socijalna psihologija. Zagreb: Mate.

3. Bahtijarević-Šiber, F. (1999). Management ljudskih potencijala, Zagreb: Golden marketing.

4. Bogardus, E. S. (1925). Measuring Social Distance. Journal of Applied Sociology, 9: 299308. Preuzeto 15. 9. 2021. sa stranice http://www. 154 brocku.ca/MeadProject/Bogardus/ Bogardus_1925c.html.

5. Ding, V. J., Stillman, J. (2005). An empirical investigation of discrimination against overweight female job applicants in New Zealand. New Zealand Journal of Psychology 34(3): 139-148.

6. Fikkan, J., Rothblum, E. (2005). Weight bias in employment. U Brownell, K. D. Puhl R. M., Schwartz M. B., Rudd L. (ur.), Weight bias: Nature, consequences, and remedies (15-28). New York: Guilford Press.

7. Giel, K. E., Zipfel, S., Alizadeh, M., Schaffeler, N., Zahn, C., Wessel, D., Hesse, F. W., Thiel, S., Thiel, A. (2012). Stigmatization of obese individuals by human resource professionals: An experimental study. BMC Public Health, 2-9.

8. Giel, K. E, Thiel, A, Teufel, M, i sur. (2010). Weight bias in work settings-A qualitative review. Obesity Facts 3(1): 33-40.

9. Klassen, M. L., Jasper, C. R., Harris, R. J. (1993). The role of physical appearance in managerial decisions. Journal of Business and Psychology, 8, 181-198.

10. Kutcher, E. J., Bragger, J. D. (2004). Selection interviews of overweight job applicants: Can structure reduce the bias? Journal of Applied Social Psychology 34, 1993-2022.

11. Larkin J. C., Pines, H. A. (1979). No fat persons need apply: experimental studies of the overweight stereotype and hiring preference. Social Worker Occupation, 6, 312-327.

12. Magallares, A., Morales, J. F., Rubio, M. A. (2011). The effect of work discrimination on the well-being of obese people. International Journal of Psychology and Psychological Therapy, 11(2), 255-267.

13. Medanić, D., Pucarin-Cvetković, J., (2012). Pretilost - javnozdravstveni problem i izazov. Acta med Croatica, 66, 347-355.

14. Morris. M., (2007). The impact of obesity on employment. Labour economics, 14, 413-433.

15. Musić Milanović, S. (2010). Demografske, bihevioralne i socioekonomske odrednice debljine odraslih u Hrvatskoj (doktorska disertacija). Sveučilište u Zagrebu.

16. Musić Milanović, S., Lang Morović M., Križan, H. (2021). Europska inicijativa praćenja debljine u djece, Hrvatska 2018./2019. (CroCOSI), Hrvatski zavod za javno zdravstvo, Zagreb.

17. Noe, R. A., Hollenbeck, J., R. (...) Wright, P. M. (2005). Menadžment ljudskih potencijala-postizanje konkurentske prednosti. Zagreb: Mate.

18. O’Brien, K. S., Latner, J. D., Ebneter, D, i sur. (2013). Obesity discrimination: The role of physical appearance, personal ideology, and anti-fat prejudice. International Journal of Obesity, 37(3) 455-460.

19. Pingitore, R, Dugoni, B.L., Tindale, R. S., Spring, B. (1994). Bias against overweight job applicants in a simulated employment interview. Journal of Applied Psychology, 79(6), 909-917.

20. Puhl, R. M., Brownell, K. D. (2003). Psychosocial origins of obesity stigma: Toward changing a powerful and pervasive bias. Obesity Reviews, 4, 213-227.

21. Robbins, S. P. i Judge, T. A. (2010). Organizacijsko ponašanje. Zagreb: Mate. 
22. Roehling M. V. (1999) Weight-based discrimination in employment: psychological and legal aspects. Personnel Psychology, 52, 969-1017.

23. Roehling, M. V. (2002). Weight discrimination in the American workplace: Ethical issues and analysis. Journal of Business Ethics, 40, 177-189.

24. Rudolph, C. W, Wells, C. L., Weller, M. D., Baltes, B. B. (2009). A meta-analysis of empirical studies of weight-based bias in the workplace. Journal of Vocational Behavior, 74: 1-10.

25. Swami, V., Furnham, A., Amin, R., Chaudhri, J., Joshi, K., Jundi, S., i sur. (2008). Lonelier, lazier, and teased: The stigmatizing effect of size. The Journal of Social Psychology, 148, 577-593.

26. Watson, L., Levit, T., Lavack, A. M. (2017). Obesity and Stigmatization at Work, u Thomson S. B. i Grandy, G. (ur.), Stigmas, Work and Organizations, New York: Palgrave Macmillan, 11-34. 